\title{
Peningkatan Hasil Belajar Luas Bangun Datar melalui Strategi Belajar Kooperatif Tipe Jigsaw bagi Siswa Kelas V SD Negeri 02 Silaut Kecamatan Silaut
}

\author{
Masril \\ SDN 02 Silaut Kecamatan Silaut
}

\begin{abstract}
This research is motivated by the fact that elementary schools that learning is often dominated by teachers as a source of information and learning models used are generally conventional, so that the learning process is less attractive to students, and learning outcomes are less satisfying. From that, the researcher through this class action research wanted to improve the results of Mathematics learning through Jigsaw type cooperative learning for the fifth-grade students of SDN 02 Silaut. The results of this study can be concluded that through Jigsaw, cooperative learning can improve student mathematics learning outcomes in class V SDN 02 Silaut District Silaut. Therefore, it is recommended that teachers can carry out the learning process through Jigsaw cooperative learning in order to improve student learning outcomes and interests.
\end{abstract}

Keywords: Jigsaw type cooperative learning, elementary school, mathematics Indonesian Institute for Counseling, Education and Therapy (IICET)

\section{PENDAHULUAN}

Secara nyata matematika sangat berguna bagi kehidupan manusia, karena matematika dapat melatih seseorang berfikir kritis dan logis, juga bermanfaat dalam melakukan perhitungan dalam kehidupan sehari-hari. Matematika sebagai salah satu disiplin ilmu merupakan pengetahuan yang sangat penting terutama dalam era globalisasi sekarang ini, dengan arti kata dalam perkembangannya, matematika tidak terlepas kaitannya dengan perkembangan ilmu pengetahuan dan teknologi (IPTEK).

Salah satu materi dalam pembelajaran matematika di SD adalah tentang geometri. Apabila ditelaah dalam Kurikulum Tingkat Satuan Pendidikan (KTSP), materi geometri ini pada umumnya dipelajari pada setiap kelas, ini membuktikan bahwa geometri merupakan salah satu materi pembelajaran yang perlu mendapat perhatian, dengan tujuan agar geometri tersebut dapat lebih dipahami dan dikuasai oleh siswa sebagaimana mestinya.

Salah satu model pembelajaran yang dapat menciptakan pembelajaran yang aktif dan menyenangkan adalah melalui pembelajaran kooperatif (cooperative learning). Mohammad (2005:2) menyatakan bahwa "dalam pembelajaran koperatif siswa belajar secara berkelompok, saling membantu satu sama lain. Siswa mengeluarkan ide-ide, konsep-konsep dan keterampilan yang mereka miliki". Dengan hal seperti ini dapat meningkatkan pemahaman siswa terhadap materi pembelajaran, karena siswa saling bekerja sama untuk menuntaskan materi belajarnya. Sehingga dapat meningkatkan hasil belajar siswa.

Melihat keunggulan dari pembelajaran kooperatif tipe Jigsaw, maka peneliti menggunakan pembelajaran kooperatif (cooperative learning) tipe Jigsaw dalam penelitian tindakan kelas dengan judul "Peningkatan Hasil Belajar Luas Bangun Datar Melalui Strategi Belajar Kooperatif Tipe Jigsaw Bagi Siswa Kelas V SDN. 02 Silaut Kecamatan Silaut". 


\section{METODE PENELITIAN}

Penelitian Tindakan Kelas ini dilaksanakan di V SDN. 02 Silaut Kecamatan Silaut. Penelitian ini dilakukan pada siswa kelas V SDN. 02 Silaut Kecamatan Silaut dengan jumlah peserta didik 26 orang yang terdiri dari 15 perempuan dan 11 laki-laki. Penelitian ini dilakukan pada semester dua bulan Januari s/d Juni tahun ajaran 2016/2017 pada kelas V SDN 02 Silaut Kecamatan Silaut.

Penelitian yang dilakukan adalah penelitian tindakan kelas dengan menggunakan pendekatan kualitatif. Jenis penelitian yang dilakukan adalah penelitian tindakan kelas (classroom Action Research) dibidang pendidikan khususnya dalam pengajaran matematika tentang luas bangun datar pada kelas $\mathrm{V}$ SDN. 02 Silaut Kecamatan Silaut. Penelitian ini dilakukan dengan menggunakan model siklus yang dikembangkan oleh Kemmis dan Mc Taggart (dalam Ritawati 2016:69).

Prosedur penelitian diantaranya: 1) studi pendahuluan/ refleksi awal; 2) penyusunan rancangan tindakan/perencanaan; 3) pelaksanaan tindakan; 4) pengamatan; and 5) refleksi.

Data dalam penelitian ini merupakan data primer yang berupa hasil pengamatan dari setiap tindakan dalam proses pembelajaran luas bangun datar melalui pembelajaran kooperatif tipe Jigsaw pada siswa kelas V SD terteliti. Data ini berupa hal-hal yang berkaitan dengan perencanaan, pelaksanaan dan hasil belajar..

Sumber data penelitian ini berasal dari proses pembelajaran luas bangun datar melalui pembelajaran kooperatif tipe Jigsaw di kelas V SD.

Instrumen yang digunakan dalam melaksanakan penelitian ini untuk mendapatkan data adalah dengan menggunakan lembar observasi, hasil tes dan dokumantasi. Berupa gambaran tentang pengamatan terhadap praktisi dalam pembelajaran menghitung luas bangun datar di kelas V SD yang dicatat pada lembaran observasi.

Data yang diperoleh dalam penelitian ini dianalisis dengan menggunakan analisis kualitatif dan kuantitatif. Analisis data kualitatif yaitu berhubungan dengan hasil pengamatan dan pencatatan lapangan. Pengamatan dan pencatatan lapangan maksudnya disini adalah pengamatan dan pencatatan lapangan tentang rancangan pembelajaran yang telah disusun untuk kegiatan proses pembelajaran, baik itu rancangan kegiatan yang akan dilakukan guru maupun siswa.

Ritawati, dkk (2016:58) menjelaskan bahwa analisis data dilakukan dengan langkah-langkah sebagai berikut : 1) Menelaah seluruh data yang telah terkumpul, baik melalui observasi maupun pencatatan lapangan dengan melakukan proses transkripsi hasil pengamatan, penyeleksian dan pemilihan data. Data maksudnya disini adalah data tentang rancangan pembelajaran yang telah disusun, baik kegiatan yang dilakukan guru maupun siswa selama proses pembelajaran. Apakah guru maupun siswa ada melaksanakan kegiatan sesuai dengan rancangan yang telah disusun; 2) Mereduksi data meliputi pengkategorian dan pengklasifikasian. Semua data yang terkumpul diseleksi dan dikelompok-kelompokkan sesuai dengan fokus penelitian. Data yang telah dipisah-pisahkan diseleksi mana yang relevan dan tidak relevan. Data yang relevan dianalisis dengan format analisis data yang telah dibuat, sedangkan data yang tidak relevan dengan rancangan yang telah disusun dibuang. Maksudnya data yang tidak berhubungan dengan permasalahan yang akan dibahas tidak perlu dimasukkan; 3) Penyajian data dilakukan dengan cara mengorganisasikan informasi yang sudah direduksi. Data disajikan terpisah-pisah tetapi setelah direduksi seluruh data dirangkum dan disajikan secara terpadu.

Analisis data dilakukan terhadap data yang telah direduksi baik data perencanaan, pelaksanaan maupun data evaluasi, secara terpisah-pisah. Hal ini dimaksud agar dapat ditemukan berbagai informasi yang spesifik dan terfokus pada berbagai informasi yang mendukung pembelajaran dan yang menghambat pembelajaran. Dengan demikian pengembangan dan perbaikan atas berbagai kekurangan dapat dilakukan tepat pada aspek yang bersangkutan. 


\section{HASIL}

\section{Siklus I}

\section{Perencanaan}

Materi yang diajarkan pada siklus I pertemuan pertama adalah pembelajaran luas bangun datar dengan menggunakan pembelajaran kooperatif tipe Jigsaw.

\section{Pertemuan I}

Kegiatan awal, menyampaikan materi yang akan dibahas serta mengadakan tanya jawab yang berhubungan dengan materi yang bertujuan untuk membuka skemata siswa, yaitu tanya jawab tentang contoh-contoh bangun datar yang diketahui siswa.

Kegiatan inti, pada kegiatan ini guru tidak memberikan tes, cukup dengan mengadakan tanya jawab saja. Karena dalam pertemuan I ini yang dituntut adalah siswa dapat menemukan kembali rumus luas bangun datar (belah ketupat, jajar genjang, layang-layang dan trapesium) dan pengaplikasian dari rumus yang telah ditemukan akan dibahas dalam pertemuan II.

Kegiatan akhir, pada kegiatan ini, hal-hal yang dilakukan oleh peneliti adalah menyimpulkan pembelajaran bersama siswa serta memberikan catatan tentang topik yang telah dibahas. Pembelajaran pada pertemuan I ini telah selesai terlaksanakan berdasarkan semua langkah-langkah yang telah disusun

\section{Pengamatan}

Proses pembelajaran ini diamati oleh teman sejawat, sedangkan proses pembelajarannya dilaksanakan oleh peneliti sendiri.

Pelaksanaan pembelajaran menemukan kembali rumus luas bangun datar melalui pembelajaran kooperatif tipe Jigsaw terlihat bahwa guru telah melaksanakan hampir seluruh tahap-tahap pembelajaran yang disusun dalam RPP, kecuali dalam memberikan penghargaan dan evaluasi guru tidak melaksanakannya karena pengaplikasian dari pembelajaran pertemuan I ini akan dibahas pada pertemuan II.

Dari uraian tentang rambu-rambu karakteristik keberhasilan guru pada halaman sebelumnya, dapat diketahui bahwasannya untuk pertemuan I ini persentase mengajar dari aspek guru yaitu $67,5 \%$ sedangkan pada aspek siswa baru mencapai $65,9 \%$.

\section{Pertemuan II}

Kegiatan awal, tindakan ini diawali dengan mengucapkan salam, menyiapkan kondisi kelas, berdo'a serta absensi. Kemudian menyampaikan materi yang akan dibahas serta memberikan appersepsi

Kegiatan inti, dalam kegiatan ini, guru meminta siswa membentuk kelompok berdasarkan kelompok yang telah terbentuk. Setelah siswa duduk dalam kelompoknya (kelompok asal). Dalam kelompok ahli, guru memberikan Lembar Kerja Siswa (LKS) yang akan didiskusikan.

Kegiatan akhir, pada kegiatan ini hal-hal yang dilakukan guru adalah bersama siswa menyimpulkan pembelajaran. Hasil tes ini digunakan untuk menentukan skor akhir yang diperoleh pada siklus I dan berguna untuk melihat keberhasilan dari siklus I.

\section{Pengamatan}

Kegiatan yang diamati adalah kegiata siswa dan guru saat proses pembelajaran berlangsung. Dari lembar pencatan lapangan, terlihat bahwa hampir seluruh langkah-langkah pembelajaran diikuti oleh siswa. Hanya saja pada kegiatan akhir siswa tidak terlibat dalam menyimpulkan pembelajaran, sehingga siswa terkesan pasif dalam menutup dan menyimpulkan pembelajaran.

\section{Refleksi}

Refleksi tindakan dilakukan untuk penyempurnaan kekurangan-kekurangan dari pelaksanaan tindakan yang disusun dalam siklus I. 


\section{Siklus II}

\section{Perencanaan.}

Hasil analisis refleksi pada siklus I menunjukkan subjek penelitian belum mencapai tujuan pembelajaran khususnya yang diharapkan. Karena itu pembelajaran dilanjutkan dengan siklus II.

Tahap Pelaksanaan.

Kegiatan awal, peneliti memulai pembelajaran dengan mengucapkan salam, menyiapkan kondisi kelas, melakukan do'a bersama, pengambilan absensi siswa dan menyampaikan tujuan pembelajaran yang ingin dicapai

Kegiatan inti, selanjutnya pembelajaran pada kegiatan inti dengan materi menyelesaikan masalah yang berkaitan dengan luas bangun datar melalui pembelajaran kooperatif tipe jigsaw.Setelah masingmasing ahli menjelaskan topik pada kelompok asalnya, guru memberikan tes pada masing-masing kelompok asal yang menyangkut seluruh topik.

Kegiatan akhir, selelai mengerjakan tes, guru mengumpulkan jawaban-jawaban siswa kemudian menjawabnya secara bersama-sama dan pengkoreksian jawabannya peneliti lakukan di rumah.

Hasil tes ini digunakan untuk menentukan skor akhir yang diperoleh pada siklus II dan berguna untuk melihat keberhasilan dari siklus II. Setelah itu guru meminta siswa berdo'a bersama untuk pulang.

\section{Pengamatan}

Dari segi guru, alokasi waktu yang telah disusun sudah dapat dimanfaatkan dengan baik, mulai dari awal pelajaran sampai akhir pelajaran. Dalam membimbing diskusi guru telah melaksanakannya dengan baik, hal ini terlihat saat siswa melaksanakan diskusi siswa tenang dalam berdiskusi.

Dari segi siswa, siswa terlihat serius dengan materi dan langkah yang dilaksanakan. b) siswa yang terpanggil ke depan kelas sudah bersedia untuk melaporkan hasil diskusinya. c) hasil diskusi siswa sudah terlihat baik,. d) soal tes yang dikerjakan siswa menampakkan siswa paham dengan masalah yang telah didiskusikan, terbukti dengan meningkatnya hasil belajar siswa.

Dari pelaksanaan pembelajaran menyelesaikan soal cerita yang berhubungan dengan luas bangun datar pada siklus II ini terlihat bahwa guru telah melaksanakan semua langkah-langkah pembelajaran yang disusun dalam RPP.

Pembelajaran menyelesaikan soal cerita yamg berhubungan dengan luas bangun datar di atas dapat kita lihat bahwasannya untuk siklus II ini persentase mengajar dari aspek guru sudah meningkat menjadi $90 \%$ sedangkan pada aspek siswa sudah mencapai 89,5\%.

\section{Refleksi}

Berdasarkan refleksi/diskusi yang dilakukan oleh peneliti dan dua orang observer, diperoleh kesimpulan bahwa dari 26 orang siswa yang mengikuti tes yang diadakan diakhir siklus II terdapat 23 orang yang mendapatkan nilai 7 keatas. Dimana rata-rata nilai siswa yang tuntas adalah 8,3 sedangkan rata-rata \% ketuntasan siswa mencapai $88,4 \%$. Sehingga dari hasil analisis tes siswa pada siklus II ini sudah dapat dikatakan tuntas, karena ketuntasan siswa sudah melebihi dari standar yang telah ditetapkan.

\section{PEMBAHASAN}

\section{Pembahasan siklus I}

Pelaksanaan pembelajaran yang aktif dan menyenangkan sangat dibutuhkan oleh siswa Sekolah Dasar, pembelajaran yang menyenangkan itu dapat dilihat pada saat siswa bekerja sama dalam kelompok. Di dalam kelompok siswa saling tolong menolong, siswa dapat dengan mudah memahami materi pelajaran. Hal ini sesuai dengan yang terdapat dalam Nur (2006:12) menyatakan bahwa "Bembelajaran kooperatif mendasarkan suatu ide bahwa siswa bekerja sama dalam kelompok dan sekaligus bertanggungjawab pada aktivitas belajar anggota kelompoknya, sehingga seluruh anggota kelompok dapat menguasai materi pelajaran dengan baik". 
Setelah pembelajaran siklus satu terlaksana hasil belajar siswa meningkat. hal ini dapat dilihat pada grafik 1 berikut:

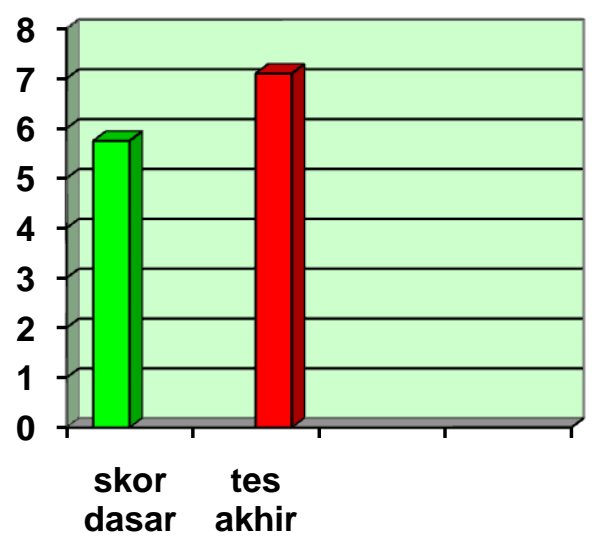

$$
\begin{aligned}
& \square \text { skor dasar } \\
& \square \text { tes akhir siklus I }
\end{aligned}
$$

Grafik 4.1

Dari analisis penelitian siklus I nilai rata-rata skor dasar 5,8 dan dapat dilihat pada diagram batang berwarna hijau. Setelah dilakukan tindakan nilai rata-rata siswa meningkat yaitu 6,9 yang digambarkan dengan diagram batang warna merah. Berdasarkan hasil pengamatan siklus I yang diperoleh maka direncanakan untuk melakukan siklus II karena ada 10 orang anak yang memperoleh nilai di bawah rata-rata. untuk itu penelti melanjutkan penelitian pada siklus II.

\section{Pembahasan siklus II}

Guru harus dapat memperhatikan perbedaan yang ada pada siswa karena tiap individu mempunyai karakteristik yang berbeda. Menurut Rochman Natawijaya (dalam Rosna, 2006:43) "Belajar adalah proses pembinaan yang terus menerus terjadi dalam diri individu yang tidak ditentukan oleh unsur ketururunan, tetapi lebih banyak ditentukan oleh faktor-faktor dari luar anak". Dalam belajar siswa banyak memperoleh dari guru, maka guru harus lebih memahami kembali ketiga aspek dalam pendidikan yaitu yang belajar, proses belajar dan situasi belajar. Adpun yang menjasi subjek belajar adalah anak didik atau siswa yang secara individu atau kelompok mengikuti proses pembelajaran dalam suasana tertentu.

Dari hasil analisis penelitian siklus II nilai rata-rata kelas mencapai 8,3 berikut peneliti sajikan grafik peningkatan nilai rata-rata kelas dari siklus I ke siklus II

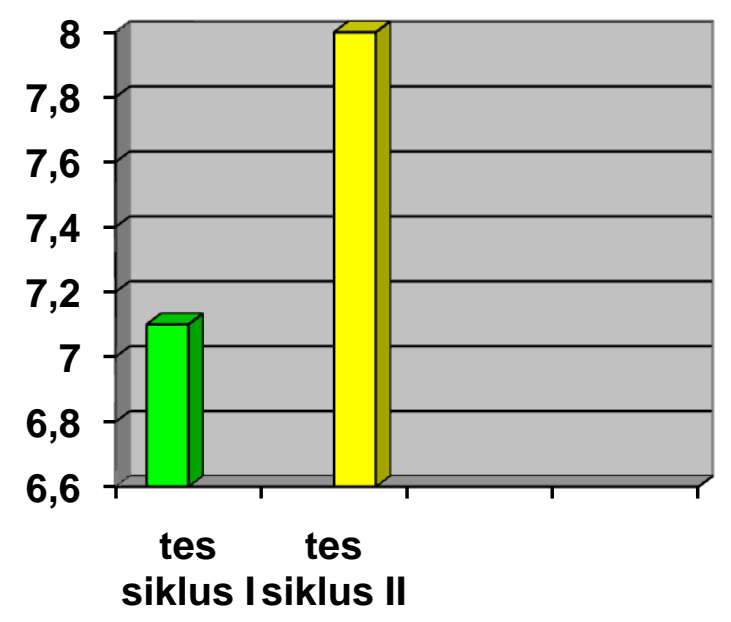

\section{$\square$ tes siklus I $\square$ tes siklus II}

Grafik 4.2 
Pada siklus I nilai rata-rata kelas 6,9 yang digambarkan dengan diagram batang warna hijau. Setelah dilakukan tindakan pada siklus II nilai rata-rata siswa meningkat menjadi 8,3 yang digambarkan dengan diagram batang warna kuning. Berdasarkan hasil pengamatan siklus II yang diperoleh maka pelaksanaan siklus II sudah baik dan guru sudah berhasil dalam usaha peningkatan hasil belajar siswa dalam pembelajaran penyelesaian masalah yang berkaitan dengan luas bangun datar dengan menggunakan pendekatan kooperatif tipe jigsaw bagi siswa kelas V SDN. 02 Silaut Kecamatan Silaut Kota Padang .

Berikut peneliti sajikan peningkatan nilai rata-rata siswa sebelum melakukan tindakan dan setelah melakukan tindakan.

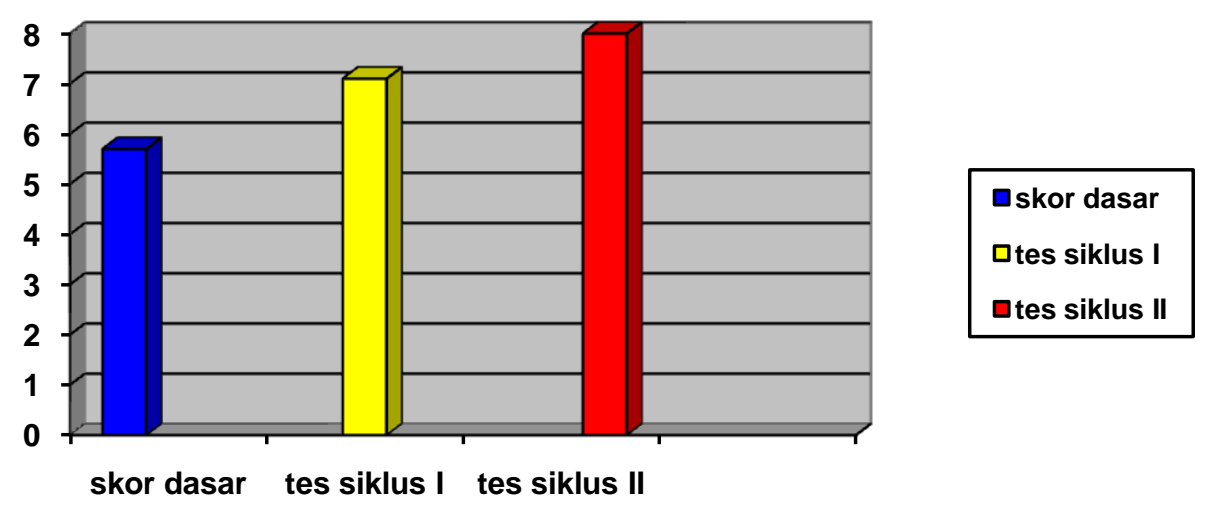

Grafik 4.3

Pada saat peneliti melakukan penelitian, peneliti mengambil skor dasar dari nilai rata-rata ujian mid semester II kelas V, dimana nilai rata-rata kelas hanya 5,8 yang dapat dilihat pada diagram batang warna biru. Kemudian peneliti melakukan tindakan siklus I dalam pembelajaran dengan menggunakan Model Pembelajaran Kooperatif tipe jigsaw nila rata-rata siswa meningkat hingga 6,9 yang digambarkan dengan diagram batang warna kuning. Setelah dilanjutkan dengan siklus II nilai rata-rata siswa meningkat menjadi 8,3 yang digambarkan dengan diagram batang warna merah. BSNP (2006:12) "kriteria ketuntasan untuk masing-masing indikator dalah $75 \%$. Namun disamping itu setiap satuan pendidikan harus manentukan kriteria ketuntasan minimal dengan mempertimbangkan tingkat kemampuan rata-rata siswa, kompleksitas kompetensi serta kemampuan sumber daya pendukung dalam penyelenggaraan pembelajaran". Dari hal itu peneliti mengambil ketuntasan yang diterapkan di SD N 15 Koto Lalang Kecamatan Lubuk Kilangan, yaitu pada mata pelajaran matematika standar ketuntasan minimalnya adalah $70 \%$ Berdasarkan hal itu penelitian ini berakhir di siklus II karena standar ketuntasan klasikalnya sudah melebihi dari target yang ditetapkan.

Pembelajaran yang disajikan pada siklus II, guru dalam memberikan motivasi sangat bagus. Pada proses pembelajaran guru banyak memberikan kesempatan kepada siswa untuk berdiskusi bersama dan bertanya tentang permasalahan yang tidak dimengerti oleh siswa. Untuk itu guru harus mampu menciptakan situasi yang menyenangkan untuk belajar. Sehingga hasil belajar siswa meningkat.

Untuk mencapai hal tersebut sudah seharusnya guru mampu menciptakan pembelajaran yang sesuai dengan kebutuhan siswa. Selain itu, guru juga harus memperhatikan keberhasilan siswa dalam memahami sesuatu dengan cara sesuai dengan tingkat kemampuan siswa. Guru bertugas membelajarkan siswa. Untuk membelajarkan siswa tersebut guru haruslah menggunakan berbagai macam cara agar pembelajaran dapat bermakna bagi siswa, seperti menggunakan pendekatan pembelajaran yang bervariasi, media pembelajaran yang sesuai dengan tujuan dan menciptakan suasana belajar yang menyenangkan bagi siswa

\section{KESIMPULAN}

Dari paparan data dan hasil penelitian serta pembahasan pada halaman terdahulu, maka peneliti dapat menarik beberapa kesimpulan, yaitu: 1) pembelajaran kooperatif tipe Jigsaw dapat membuat 
siswa lebih aktif dalam belajar, dapat meningkatkan sikap kerja sama karena pembelajarannya dilakukan secara berkelompok. Hal ini dapat terlaksana karena masing-masing anggota kelompok harus menguasai topik yang telah dibahas dan menyampaikan topik itu kepada anggota kelompoknya. Dengan kata lain pembelajaran kooperatif tipe Jigsaw dapat menumbuhkan tanggung jawab siswa terhadap materi yang dipelajarinya dan harus mengajarkan materi tersebut kepada temannya, sehingga siwa termotivasi untuk aktif dan serius dalam pembelajaran; 2) meningkatnya hasil belajar siswa dapat dilihat dari rata-rata nilai siswa dari tes awal 5,8 meningkat pada siklus I menjadi 6,9 pembelajaran belum dianggap tuntas jika hasil yang diperoleh di bawah $70 \%$ dan untuk itu penelitian ini dilanjutkan pada siklus II. Ternyata Pelaksanaan tindakan pada siklus II mengalami peningkatan yakni 8,3 yang sudah melebihi dari standar ketuntasan minimalnya. Hal ini merupakan bukti dari pelaksanaan penelitian yang telah dilakukan di V SDN. 02 Silaut Kecamatan Silaut telah berhasil.

\section{DAFTAR RUJUKAN}

Akhmad Sudrajat. (2016). Penelitian Tindakan Kelas (Part II). online (http:akhmadsudrajat.worpress.com/2016/03/21/penelitian-tindakan-kelas-part-ii/ diakses 5 Maret 2017)

Anas Sudijono. (2007). Pengantar Evaluasi Pendidikan. Jakarta : PT Raja Grafindo Persada

Antonius Cahya Prihandoko. (2006). Pemahaman dan Penyajian Konsep Matematika Secara Benar dan Menarik. Jakarta : Depdiknas

Aristo Rahadi. (2003). Media Pembelajaran. Jakarta : Depdiknas

Badan Standar Nasional Pendidikan (BSNP). (2006). BSNP. Jakarta : BSNP

Badan Standar Nasional Pendidikan (BSNP). (2016). Kurikulum Tingkat Satuan Pendidikan (KTSP). Jakarta : BSNP

Depdiknas. (2005). Materi Pelatihan Terintegrasi Matematika. Jakarta : Depdiknas

Erman Suherman, dkk. (2003). Strategi Pembelajaran Matematika Kontemporer. Bandung : JICA

Etin Solihatin. (2007). Cooperative Learning Analisis Model Pembelajaran IPS. Jakarta : Bumi Aksara

Harun Rasyid, dkk. (2007). Penilaian Hasil Belajar. Bandung : CV Wacana Prima

I.G.A.K Wardani, dkk. (2002). Penelitian Tindakan Kelas. Jakarta : Universitas Terbuka

Indriyastuti. (2016). Matematika Kelas III SD. Jawa Timur ; PT. Tiga Serangkai Pustaka Mandiri

Karso,dkk.(1998).Materi pokok pendidikan matematika I.Jakarta: universitas Terbuka

Kunandar. (2016). Guru Profesional Implementasi KTSP dan Sukses dalam Sertifikasi Guru. Jakarta : PT. Raja Grafindo Persada

Masnur Muslich. (2007). KTSP Dasar Pemahaman dan Pengembangan. Jakarta: Bumi Aksara

Mohammad Nur. (2005). Pembelajaran Kooperatif. Surabaya : Depdiknas

Mulyana. (2007) . Tip dan Trik Berhitung Super Cepat dengan Konsep Rahasia Matematika. Surabaya : Agung Media Mulya

Nur Asma. (2006). Model Pembelajaran Kooperatif. Jakarta : Depdiknas

Nur Asma. (2016). Model Pembelajaran Kooperatif. Padang : UNP Pres

Sri Subarinah. (2006). Inovasi Pembelajaran Matematika Sekolah Dasar. Jakarta : Depdiknas

Suharsimi Arikunto, dkk. (2004). Evaluasi Program Pendidikan. Jakarta : PT.Bumi Aksara

Ritawati Mahyuddin, dkk. (2016). Hand Out Metodologi Penelitian Tindakan Kelas. Padang : UNP

Rochman Natawijaya. (1992). Psikologi Pendidikan. Jakarta : Depdikbud

Rosna. (2006). Peningkatan Hasil Belajar Geometri Dalam Penbelajaran melalui Penggunaan Media Bangun Datar bagi Siswa Kelas IV SDN 18 Kota Panjang. Skripsi tidak diterbitkan. Padang.PGSD.UNP.

Wina Sanjaya. (2016). Strategi Pembelajaran. Jakarta : Kencana Prenada Media Group

Zahara Djafar. (2001). Konstribusi Strategi Pembelajaran Terhadap Hasil Belajar. Padang : FIP UNP 